Article

\title{
Gap Size in Hyrcanian Forest Affects the Lignin and N Concentrations of the Oriental Beech (Fagus orientalis Lipsky) Fine Roots but Does Not Change Their Morphological Traits in the Medium Term
}

\author{
Alireza Amoli Kondori ${ }^{1}$, Kambiz Abrari Vajari ${ }^{1, *}$, Mohammad Feizian ${ }^{1}$, Antonio Montagnoli ${ }^{2}$ \\ and Antonino Di Iorio ${ }^{2}$ \\ 1 Faculty of Agriculture and Natural Resource, Lorestan University, Khorramabad 6815144316, Iran; \\ amolikondori@gmail.com (A.A.K.); feizian.m@lu.ac.ir (M.F.) \\ 2 Department of Biotechnology and Life Science, University of Insubria, 21100 Varese, Italy; \\ antonio.montagnoli@uninsubria.it (A.M.); antonino.diiorio@uninsubria.it (A.D.I.) \\ * Correspondence: kambiz.abrari2003@yahoo.com; Tel.: +98-911-344-1571
}

check for updates

Citation: Kondori, A.A.; Vajari, K.A.; Feizian, M.; Montagnoli, A.; Di Iorio, A. Gap Size in Hyrcanian Forest Affects the Lignin and $\mathrm{N}$

Concentrations of the Oriental Beech (Fagus orientalis Lipsky) Fine Roots but Does Not Change Their Morphological Traits in the Medium Term. Forests 2021, 12, 137. https://doi.org/10.3390/f12020137

Academic Editor:

Antonio Montagnoli

Received: 16 December 2020

Accepted: 21 January 2021

Published: 26 January 2021

Publisher's Note: MDPI stays neutral with regard to jurisdictional claims in published maps and institutional affiliations.

Copyright: (C) 2021 by the authors Licensee MDPI, Basel, Switzerland. This article is an open access article distributed under the terms and conditions of the Creative Commons Attribution (CC BY) license (https:// creativecommons.org/licenses/by/ $4.0 /)$.

\begin{abstract}
Research Highlights: Fine roots play an important role in plant growth as well as in carbon (C) and nutrient cycling in terrestrial ecosystems. Gaining a wider knowledge of their dynamics under forest gap opening would improve our understanding of soil carbon input and belowground carbon stock accumulation. Single-tree selection is increasingly recognized as an alternative regime of selection cutting sustaining biodiversity and carbon stock, along with timber production, among ecosystem functions. However, the fine root response in terms of morphological and chemical composition to the resulting harvest-created gaps remains unclear. Background and Objectives: This paper investigates the effect in the medium term (i.e., 6 years after logging) of differently sized harvest-created gaps on fine root dynamics and chemical composition. Materials and Methods: A total of 15 differently sized gaps (86.05-350.7 $\mathrm{m}^{2}$ ) and the adjacent $20 \mathrm{~m}$ distant closed canopies (control) were selected in a temperate Fagus orientalis forest (Hyrcanian region, Iran). Eight soil cores were collected at the cardinal points of the gap edge, including four facing the gap area-the same at the adjacent intact forest. Results: For the selected edge trees, the different size of gaps, the core position, and the tree orientation did not affect the investigated morphological traits, except for the slightly higher specific root length (SRL) for the larger fine root fraction (1-2 mm) in the side facing the gap area. Differently, the investigated chemical traits such as $\mathrm{N}$ concentration and cellulose:lignin ratio significantly increased with increasing gap size, the opposite for C:N ratio and lignin. Moreover, $\mathrm{N}$ concentration and C:N significantly decreased and increased with the fine root diameter, respectively. Conclusions: This work highlighted that, in the medium term and within the adopted size range, artificial gap opening derived from single-tree selection practice affected the chemistry rather than the biomass and morphology of gap-facing fine roots of edge trees. The medium term of six years after gap creation might have been long enough for the recovery of the fine root standing biomass to the pre-harvest condition, particularly near the stem of edge trees. A clear size threshold did not come out; nevertheless, $300 \mathrm{~m}^{2}$ may be considered a possible cut-off determining a marked change in the responses of fine roots.
\end{abstract}

Keywords: forest gap; forest management; fine roots; morphology; lignin; carbon; nitrogen; Fagus orientalis

\section{Introduction}

Fine roots (diameter $<2 \mathrm{~mm}$ ) are the most dynamic and sensitive component within the overall root system [1,2], playing a crucial role in water and nutrient acquisition [3]. They have also been regarded as short-lived and recognized as the most important component contributing to below-ground $\mathrm{C}$ and $\mathrm{N}$ fluxes in forest ecosystems [4,5]. Indeed, 
estimation of fine root production accounts for as much as 33-67\% of the total annual net primary production (NPP) [6], although fine root biomass contributes relatively little to total forest biomass, usually $<5 \%$ [7]. Furthermore, fine root mortality contributes from 18 to $58 \%$ of total $\mathrm{N}$ to forest soils, making the root litter $\mathrm{N}$ addition higher than that from above-ground litterfall in some ecosystems [4,5].

Fine root biomass has been found to vary with forest stand characteristics, i.e., tree species, stand age, density, basal area, canopy openness and soil properties, or environmental factors such as air temperature, amount of precipitation, geographical location, and elevation. In general, changes in canopy openness resulting from differently shaped gaps or coppice conversion to high forest highlighted a significant decrease in fine root biomass in the exposed soil [8-10]. For both types of management practices, fine root biomass has been found to decrease in the exposed soil surface of the gap center and proportionally to its increasing size [9,11], and reduced basal area [12]. Morphological traits related to fine root biomass also vary with gap opening since the mean diameter of the fine root population changes with change in the soil moisture caused by the opening in the canopy cover $[13,14]$. For example, under drier soil conditions, plants produce longer and finer roots $[13,15]$, which results in a relatively greater length per unit mass, thereby leading to an increase in specific root length (SRL, length-to-mass ratio). Concerning the chemical traits related to the fine root biomass, carbon and nitrogen concentrations are well known to change with changes in diameter classes, branching order [16,17], and seasonality $[16,18]$. In beech forests, for example, fine root $\mathrm{C}$ and $\mathrm{N}$ concentrations show a reverse pattern compared to each other, with the highest and lowest values for $\mathrm{C}$ concentration in July and October, respectively [18]. However, how fine root morphological and chemical traits vary with gap size is still poorly investigated.

Forest ecosystems are exposed to natural disturbances, which can have a serious impact on their functioning especially in a worsening global climate scenario [19]. In particular, disturbances such as diseases [20-22], storm [23,24], fire [25] may cause injuries to trees enough to cause the formation of forest gaps. In temperate broadleaf forests, where large-scale disturbances are rare, natural regeneration occurs predominantly in gaps [26,27]. Therefore, forest management that approximates nature, such as single-tree selection practice, appears to be a flexible and useful tool to secure sustainable forest development in terms of biodiversity [26,27] and uneven-aged forests [28]. This tool mimics natural openings of various sizes that follow moderate disturbance events [29]. On the other hand, both natural and artificial gaps induce the alteration of microclimate conditions (i.e., soil moisture and temperature, irradiance) either inside or in the proximity of the gaps [30], leading to below-ground responsive adjustments in terms of fine root dynamics whose magnitude may change with the increasing size of the gap [11]. Therefore, unveiling the threshold that could lower the impact on fine root morphological and chemical traits of edge trees may be of interest for sustainable forest management, which would lead to a higher amount and lasting in time below-ground carbon stock accumulation. This is particularly relevant as no common agreement exists on the definition of the size class of the gap; for example, the small criterion ranges from 300 [29], 700 [31,32] to $1250-1960 \mathrm{~m}^{2}$ [29].

Differences in fine root biomass among forest stands have been modeled to change also from stand initiation to a later stage of stand development (canopy closure) [33]. In particular, short-lived fine roots generally $<0.5 \mathrm{~mm}$ in diameter [34,35] and characterized by higher turnover rate are predominant during the first years following thinning operations [36,37]. For this reason, short-term (1-4 years) studies may not adequately track the fine root fraction characterized by a higher longevity and that mostly contribute to the standing biomass $[36,37]$. Thus, choosing the sampling time since the gap opening occurred is crucial for a correct estimation of the fine root standing biomass, and medium-term investigation may be considered a good compromise.

Fine root form and function may differ among branching orders $[38,39]$ and the shortcomings of the diameter-based approach are widely recognized [40]. Therefore, in this study, the size class approach was maintained for a better discrimination between the 
$<0.5 \mathrm{~mm}$ diameter class (i.e., very fine roots), which represent the most dynamic component of the root system, and the 0.5-1 and 1-2 mm diameter classes, which represent the more stable and woodier portion [41-43].

Oriental (or eastern) beech (Fagus orientalis Lipsky) forests represent the most important tree cover in the temperate-broadleaved forest in northern Iran, playing a key role in forestry activities. Caspian forests of Iran have been harvested under different silvicultural systems, such as shelterwood cutting or single-tree selection, which leads to different canopy openness [19]. Single-tree selection is increasingly recognized as an alternative regime of selection cutting sustaining biodiversity, recruitment and carbon stock, along with timber production, among ecosystem functions [44]. Many studies were conducted about different features of $F$. orientalis trees, but few on the fine roots [31,32] and their response at the morphological and chemical level to the different-sized gaps.

In this study, the two-fold hypothesis was that, in the medium term, gap openings might: (i) induce a reduction in fine root biomass greater than in length and, consequently, increase the specific root length (SRL), and (ii) increase the metabolism of fine roots leading to a higher $\mathrm{N}$ concentration. These variations would be of greater magnitude with the increasing gap size. To test these hypotheses, for trees positioned at the edge of differentsized gaps, fine root biomass, length, and tissue density were measured together with C, $\mathrm{N}$, lignin, and cellulose concentrations. This approach was intended to use the F. orientalis tree fine root morpho-chemical traits as indicators of a threshold gap size above which a significant influence on tree ecophysiology may occur.

\section{Materials and Methods}

\subsection{Study Area}

To study the effects of gap size on fine roots properties, a broadleaved Fagus orientalis L. forest, covering an area of 40.4 ha, was selected in the Caspian area (Mazandaran province), northern Iran $\left(36^{\circ} 12^{\prime} \mathrm{N}, 53^{\circ} 24^{\prime} \mathrm{E}\right)$. The general characteristics of this area were already described in a previous work carried out on the same site [45]. Briefly, the study site is located at an elevation of $1000-1200 \mathrm{~m}$ a.s.l., on a north-facing slope of $0-30 \%$. The climate is humid with a mean annual temperature of $10.5^{\circ} \mathrm{C}$ and a mean annual precipitation of $858 \mathrm{~mm}$. The pseudogleyic and gley are the dominant soil types. The shadeadapted and broadleaved $F$. orientalis trees occupy all canopy layers, from overtopped to dominant ones, and other tree species including hornbeam (Carpinus betulus), alder (Alnus subcordata), and maple (Acer velutinum) are also present. The oriental beech stand in the study site is multi-layered, uneven-aged, and developed from natural regeneration. At the time of fine root sampling, the stand density was 178 trees ha ${ }^{-1}$, with a mean tree height and diameter at breast height $(\mathrm{DBH})$ of $30.95 \pm 0.79 \mathrm{~m}$ (mean $\pm \mathrm{SE}$ ) and $58.83 \pm 2.37 \mathrm{~cm}$, respectively. No natural disturbance regime, such as storm, heavy snow or fire, is recorded in the forestry plan. The silvicultural practice historically adopted is the single-tree selection, which produced different-sized artificial gaps depending on the crown size of the harvested tree.

\subsection{Experimental Design}

In 2011, 45 gaps were randomly opened on the stand by felling different-sized trees. A $50 \mathrm{~m}$ buffer of trees was maintained between all gaps, equal to twice the diameter of the largest gap. Forest harvesting operations were conducted to prevent soil disturbance as much as possible within the stand. In total, 15 elliptical different-sized gaps ranging from 86.05 to $350.7 \mathrm{~m}^{2}$ were selected for this study. Detailed information on gap and related tree sizes are reported in Table S1. Each single gap was considered as the experimental unit, making this experimental design a point comparison approach rather than a replicated experiment on the ecosystem scale. The gap area was measured using the formula for an ellipse: $A=(\pi L W) / 4$, where $L$ and $W(\mathrm{~m})$ are the longest and the largest perpendicular to $\mathrm{L}$ distances within the gap, respectively (Figure 1). These distances were measured between stems of the edge trees. All gaps were oriented with the short distance $\mathrm{W}$ always 
parallel to the north direction. To compare with undisturbed forest, the adjacent $20 \mathrm{~m}$ distant closed-canopy clustered trees (uncut control) were selected for each gap size.

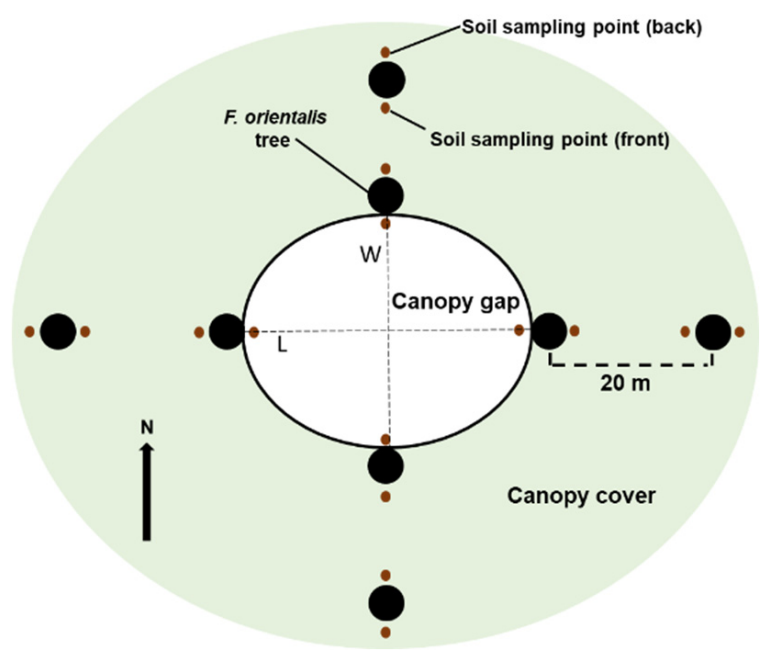

Figure 1. Sketch of location of the sampling points in the gap (white area) and adjacent intact forest (light green area). Large black circles indicate the sampled trees, small brown circles the soil core position, in the front and back of the selected trees. Dashed L and W lines indicate the distances among stems used for ellipse calculation. All gaps were oriented with the short distance of the ellipse always parallel to the north direction.

\subsection{Fine Root Sampling}

Field sampling of fine roots was carried out late in the growing season in October 2017 in all 15 artificial gaps and adjacent intact forest, i.e., 6 years after gap creation. Soil samples were collected by hand soil corer (Root Auger $80 \mathrm{~mm}$ inner diameter, ELE International, Bedfordshire, UK) to $20 \mathrm{~cm}$ soil depth at $1 \mathrm{~m}$ distance from the trunk. The sampling protocol followed the scheme reported in Figure 1 [41]. For each gap, eight soil cores were collected at the cardinal points of the gap border, and eight at the adjacent intact forest at $20 \mathrm{~m}$ from the gap. Of the eight cores, four were sampled in the side facing the gap area (front) and four on the opposite side (back). Core samples were stored in plastic bags in a commercial cool box (mod. 9315, Gio Style Spa, Italy) including ordinary freezer packs, transported to the laboratory, and kept at $4{ }^{\circ} \mathrm{C}$ until processed.

\subsection{Morphological Features of Fine Roots}

In the laboratory, all soil samples were washed on a sieve ( $1 \mathrm{~mm}$ mesh size) to remove the soil. Soil freed fine roots were further cleaned from soil residues under a stereo-microscope, and beech fine roots were distinguished from other understory roots by morphological characteristics. Beech fine roots appear reddish and stiffer than the understorey roots; these morphological characteristics were previously established from samples dug near the tree. Fine root samples were then scanned at a resolution of $500 \mathrm{dpi}$ with a calibrated flatbed scanner coupled to a lighting system (Expression 10,000 XL, Epson America Inc., Long Beach, CA, USA). The resulting images were analyzed with WinRhizo Pro V. 2007d software (Regent Instruments Inc., Quebec, QC, Canada), which, setting the diameter classes with different colors, made it possible to group with high accuracy the root axes in three diameter classes $(<0.5 ; 0.5-1.0 ; 1.0-2.0 \mathrm{~mm})$; root axes were separated from each other where necessary with scissors or scalpels. The morphometric measurements as length and mean diameter were performed. Successively, fine-roots belonging to each diameter class were grouped, oven-dried at $70{ }^{\circ} \mathrm{C}(48 \mathrm{~h})$, and weighed for dry mass measurements. Morphometric data, together with dry weight data, were also used to calculate the relative morphological traits specific root length (SRL, $\mathrm{m} \mathrm{g}^{-1}$ ) and root tissue density (RTD, $\mathrm{g} \mathrm{cm}^{-3}$ ). 


\subsection{Chemical Composition of Fine Roots}

In our samples, as the dry weight per core sample for the three fine root diameter classes ranged from 0.05 to $0.87 \mathrm{~g}$, the amount was not sufficient for testing the chemical properties, particularly for very fine roots. Then, in the laboratory, for each diameter class, all eight cores for each gap size were pooled together, the same for the closed canopy, resulting in one sample per diameter class per gap size, i.e., 15 per diameter class in total. Successively, only 9 gap sizes were selected by eliminating the even values from the series of 15 gaps $(2,4,6 \ldots$ sample). In detail, every even sample was equally split, one half pooled with the previous sample and the second half with the successive one. In this way, the critical amount of 2-3 g per sample has been achieved, totaling 18 samples corresponding to 9 gaps and 9 closed canopies for each diameter class (54 in total). Each of the 54 samples was ground in liquid nitrogen with mortar and pestle and milled to pass a 40-mesh (37 $\mu \mathrm{m}$ mesh opening) screen; the powder was used for carbon, nitrogen, lignin, cellulose, and phosphorus concentrations measurement.

\subsubsection{Carbon and Nitrogen}

C and N concentrations were measured with a CHN analyzer (NA-2000 N-Protein; Fisons Instruments S.p.A., Rodano [MI], Italy). The analyzer was calibrated with an atropine standard (Sigma-Aldrich, A-0132, St. Louis, Missouri, MO, USA) and every 10th sample with an atropine sample. The mean total $\mathrm{N}$ and $\mathrm{C}$ recovery rate for nutrient analysis of atropine was $100.28 \pm 0.59 \%$ and $100.62 \pm 0.22 \%$, respectively.

\subsubsection{Cellulose and Lignin}

The method used to measure total cellulose content was based on that developed by Leavitt and Danzer $[46,47]$ and consisted of removing as many non-cellulosic compounds as possible from the root material. The first compounds to be removed were lipids (waxes, oils, and resins). Each sample was poured into a Teflon sachet (no. 11803, pore size $1.2 \mu \mathrm{m}$ ) and in groups of nine placed into a soxhlet extractor $(50 \mathrm{~mm}$ i.d., $200 \mathrm{~mL}$ capacity to siphon top, mod. 64826, Supelco I Sigma-Aldrich) equipped with a flask containing a $700 \mathrm{~mL}$ mixture of toluene $99 \%$-ethanol $96 \%(2-1 ; v / v)$ heated until boiling point. After $24 \mathrm{~h}$ of extraction, the extractor solution was replaced with $700 \mathrm{~mL}$ of ethanol heated to the same temperature. After $24 \mathrm{~h}$, the samples were removed from the soxhlet and immersed in distilled water heated to $100{ }^{\circ} \mathrm{C}$ for $6 \mathrm{~h}$. This process removes hydrosoluble molecules from the sample. The second compounds to be removed were lignin. All samples were placed in a $250 \mathrm{~mL}$ beaker containing $160 \mathrm{~mL}$ of distilled water, $1.5 \mathrm{~g}$ of sodium chlorite $\left(\mathrm{NaClO}_{2}\right)$, and $0.5 \mathrm{~mL}$ of acetic acid. The sample and solution were shaken using a magnetic stirrer and heated to $70-80{ }^{\circ} \mathrm{C}$ for $1 \mathrm{~h}$ (this procedure was repeated three times, $3 \mathrm{~h}$ in total). After the flask was cooled to a constant temperature, the sample was removed and filtered using a filter flask and washed with distilled water until it was free from acid. The samples were dried at ambient temperature during $12 \mathrm{~h}$ and weighed. The percentage of cellulose was evaluated by calculating the relative difference in the initial and final weight of each sample $(0.5 \mathrm{~g})$.

Lignin content was measured according to a previous protocol [48], with minor modifications. For lignin extraction, $1 \mathrm{~g}$ of powdered sample was poured in a $15 \mathrm{~mL}$ plastic falcon and boiled with $2 \mathrm{~mL}$ ethanol for $30 \mathrm{~min}$ and left overnight on a tilting plate. After centrifugation, Falcons were centrifuged at $10,000 \times \mathrm{g}$ for $15 \mathrm{~min}$ at $25^{\circ} \mathrm{C}$, the supernatant removed and the pellet homogenized in $10 \mathrm{~mL}$ of extraction buffer $(50 \mathrm{mM}$ Tris- $\mathrm{HCl}, 0.01 \%$ Triton X$100\left(10 \mathrm{~g} \mathrm{~L}^{-1}\right), 1 \mathrm{M} \mathrm{NaCl}, \mathrm{pH}$ 8.3). The suspension was stirred, centrifuged at $10,000 \times g$ for $10 \mathrm{~min}$, washed twice with $4 \mathrm{~mL}$ of extraction buffer, twice with $2 \mathrm{~mL}$ of $80 \%(v / v)$ acetone, and twice with $2 \mathrm{~mL}$ of acetone, and then dried in a concentrator. Each pellet was then treated with $0.4 \mathrm{~mL}$ of thioglycolic acid and $2 \mathrm{~mL}$ of $2 \mathrm{M} \mathrm{HCl}$, for $4 \mathrm{~h}$, at $95^{\circ} \mathrm{C}$, centrifuged at $15,000 \times g$ for $10 \mathrm{~min}$ and washed three times with distilled water. Lignothioglycolic acid from each pellet was then extracted with $2 \mathrm{~mL}$ of $0.5 \mathrm{M} \mathrm{NaOH}$, under stirring for $16 \mathrm{~h}$, at $25^{\circ} \mathrm{C}$. The supernatant was acidified with $0.4 \mathrm{~mL}$ of $37 \%(v / v) \mathrm{HCl}$ in proportion $1: 5$ to 
the sample volume. Lignothioglycolic acid was then precipitated at $4{ }^{\circ} \mathrm{C}$, for $4 \mathrm{~h}$, recovered by centrifugation at $15,000 \times g$ for $20 \mathrm{~min}$, and dissolved in $1 \mathrm{~mL}$ of $0.5 \mathrm{M} \mathrm{NaOH}$. The lignin amount within each sample was calculated by measuring the absorbance at $280 \mathrm{~nm}$, using a specific absorbance coefficient of $6.0 \mathrm{~L} \mathrm{~g}^{-1} \mathrm{~cm}^{-1}$. Because this specific absorbance coefficient provides only an approximate conversion (the absorbance of lignothioglycolic acid from different sources can vary considerably; see Doster and Bostock [48]), all readings were normalized to the specimen with the highest lignin content [49].

\subsection{Statistical Analyses}

To compare the different gap sizes and the difference between the fine roots facing the gap and those facing the opposite side for each cardinal point, 15 artificial gaps of increasing size and 15 adjacent $20 \mathrm{~m}$ distant uncut control plots were established. In this work, no a priori subjective thresholds, such as small, medium and large sizes, have been adopted within the considered gap size range $\left(86.05-350.70 \mathrm{~m}^{2}\right)$, so gap size was used as a covariate in the analysis of covariance (ANCOVA). Two-way ANCOVA was performed to evaluate the effects of the fixed factor core position (front, back) and edge tree orientation ( $\mathrm{N}$, $\mathrm{S}, \mathrm{E}, \mathrm{W})$, as well as their interaction, and the covariate gap size on several morphological traits of fine roots with diameters of $<0.5,0.5-1.0$ and $1.0-2.0 \mathrm{~mm}$. For chemical traits (Section 2.4), as fine root samples were pooled, a one-way ANCOVA was performed with the diameter classes as a fixed factor and the gap size as a covariate. All uncut control data were pooled as one and treated as a control.

Data were square-root or log-transformed where necessary to meet normality and homoscedasticity assumptions. Data given in figures are not transformed; $p$ and $\mathrm{R}^{2}$ values of regression analysis refer to data transformed where necessary. All statistical analyses were performed with SPSS version 20.0 (IBM, Armonk, NY, USA) software and were performed with a $5 \%$ rejection level.

\section{Results and Discussion}

\subsection{Morphological Traits}

For the edge trees, the different size of gaps did not affect the investigated morphological traits, neither the core position nor the tree orientation (Table 1). If pooled, the mean values of all morphological traits did not differ from those of the uncut control (closed canopy), independently from the size of gaps (Figure 2); some deviations either above or below the control mean occurred in the center-left of the distribution, i.e., for the smaller gap sizes. The only exception was the slightly higher SRL for the larger fine root fraction (1-2 mm) in the side facing the gap area (Figure 3), which marginally missed the significance (core position $p=0.071$; Table 1 ).

Table 1. F and $p$ values of ANCOVA (General Linear Model) for the effects of core position and orientation on morphological fine root traits divided by diameter classes. Gap sizes were used as covariates. Interactions were not significant and therefore excluded from the model.

\begin{tabular}{|c|c|c|c|c|c|c|c|}
\hline \multirow{2}{*}{ Fine Root Trait } & \multirow{2}{*}{$\begin{array}{l}\text { Diameter } \\
(\mathrm{mm})\end{array}$} & \multicolumn{2}{|c|}{$\begin{array}{l}\text { Core Position } \\
\quad(\mathrm{df}=1)\end{array}$} & \multicolumn{2}{|c|}{$\begin{array}{l}\text { Orientation } \\
\quad(\mathrm{df}=3)\end{array}$} & \multicolumn{2}{|c|}{$\begin{array}{l}\text { Gap Size (c) } \\
\quad(\mathrm{df}=1)\end{array}$} \\
\hline & & $\mathbf{F}$ & $p$ & $\mathbf{F}$ & $p$ & $\mathbf{F}$ & $p$ \\
\hline \multirow{3}{*}{ Length $\left(\mathrm{m} \mathrm{m}^{-2}\right)$} & 0.5 & 0.125 & 0.724 & 0.343 & 0.794 & 0.087 & 0.768 \\
\hline & $0.5-1$ & 0.054 & 0.817 & 0.031 & 0.993 & 0.152 & 0.697 \\
\hline & $1-2$ & 0.274 & 0.601 & 0.163 & 0.921 & 0.510 & 0.476 \\
\hline \multirow{3}{*}{ Dry mass $\left(\mathrm{g} \mathrm{m}^{-2}\right)$} & 0.5 & 0.009 & 0.924 & 0.329 & 0.805 & 0.007 & 0.935 \\
\hline & $0.5-1$ & 0.067 & 0.796 & 0.338 & 0.798 & 0.030 & 0.862 \\
\hline & $1-2$ & 0.843 & 0.360 & 0.207 & 0.891 & 0.253 & 0.616 \\
\hline \multirow{3}{*}{$\operatorname{RTD}\left(\mathrm{g} \mathrm{cm}^{-3}\right)$} & 0.5 & 0.405 & 0.525 & 0.387 & 0.762 & 0.137 & 0.712 \\
\hline & $0.5-1$ & 0.096 & 0.756 & 1.220 & 0.303 & 1.387 & 0.240 \\
\hline & $1-2$ & 1.082 & 0.299 & 0.822 & 0.483 & 0.844 & 0.359 \\
\hline \multirow{3}{*}{$\operatorname{SRL}\left(\mathrm{m} \mathrm{g}^{-1}\right)$} & 0.5 & 0.687 & 0.408 & 0.434 & 0.729 & 0.804 & 0.371 \\
\hline & $0.5-1$ & 0.001 & 0.998 & 0.671 & 0.571 & 0.659 & 0.418 \\
\hline & $1-2$ & 3.296 & 0.071 & 1.230 & 0.299 & 0.135 & 0.714 \\
\hline
\end{tabular}

RTD, Root Tissue Density; SRL, Specific Root Length; (c), covariate 


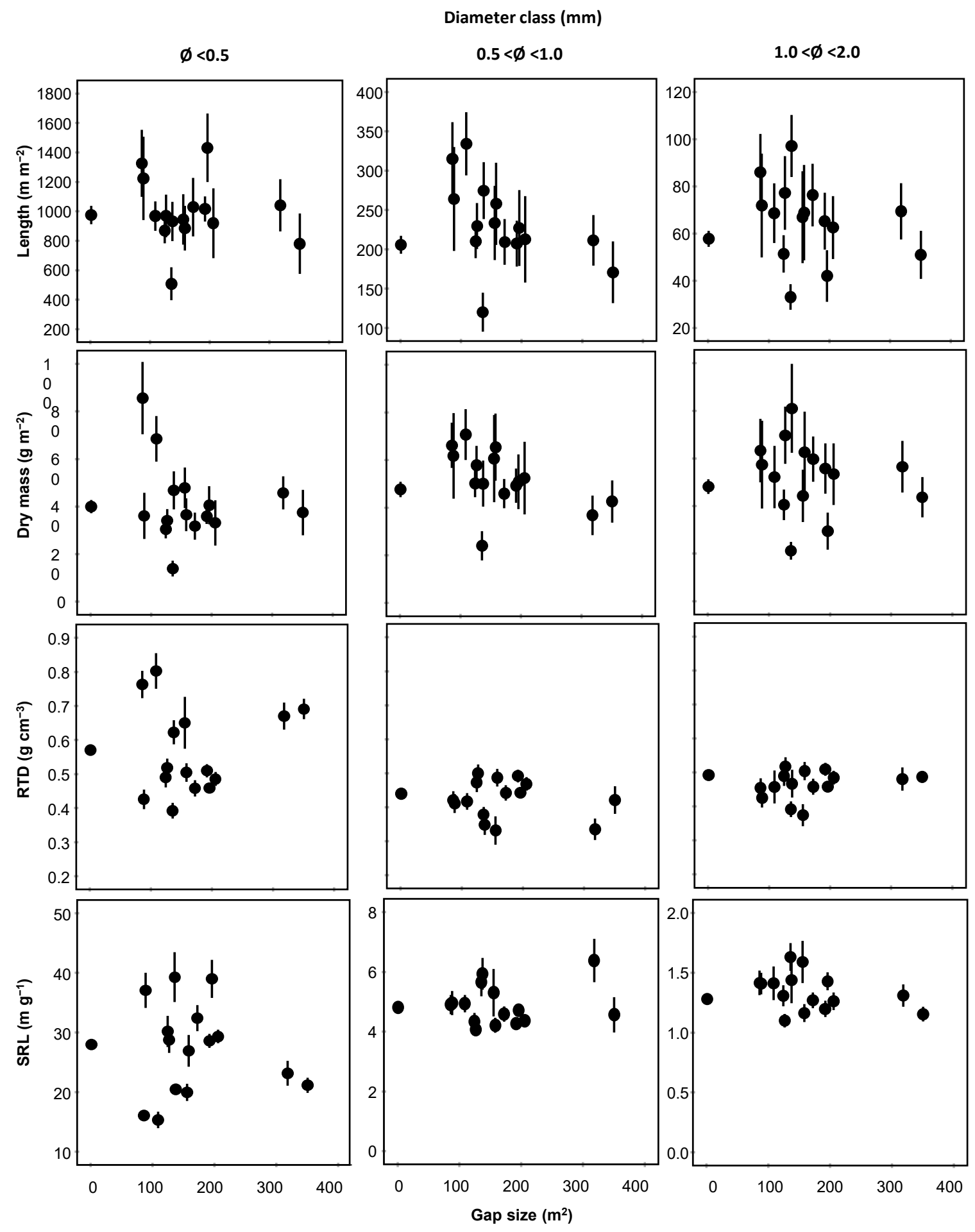

Figure 2. Fine root length, dry mass, root tissue density (RTD), and specific root length (SRL) (columns), according to three diameter classes $(<0.5,0.5-1$, and 1-2 $\mathrm{mm}$ ) (rows), in relation to gap size. Each point represents the mean of 8 replicates (front and back position and orientation pooled together) \pm SE. The uncut control was conventionally assigned the gap size value of $1 \mathrm{~m}^{2}$ and was the mean of 120 replicates (front and back position, orientation, and 15 gap size pooled together). If not reported, the scale for a given variable is the same for all the three panels. 


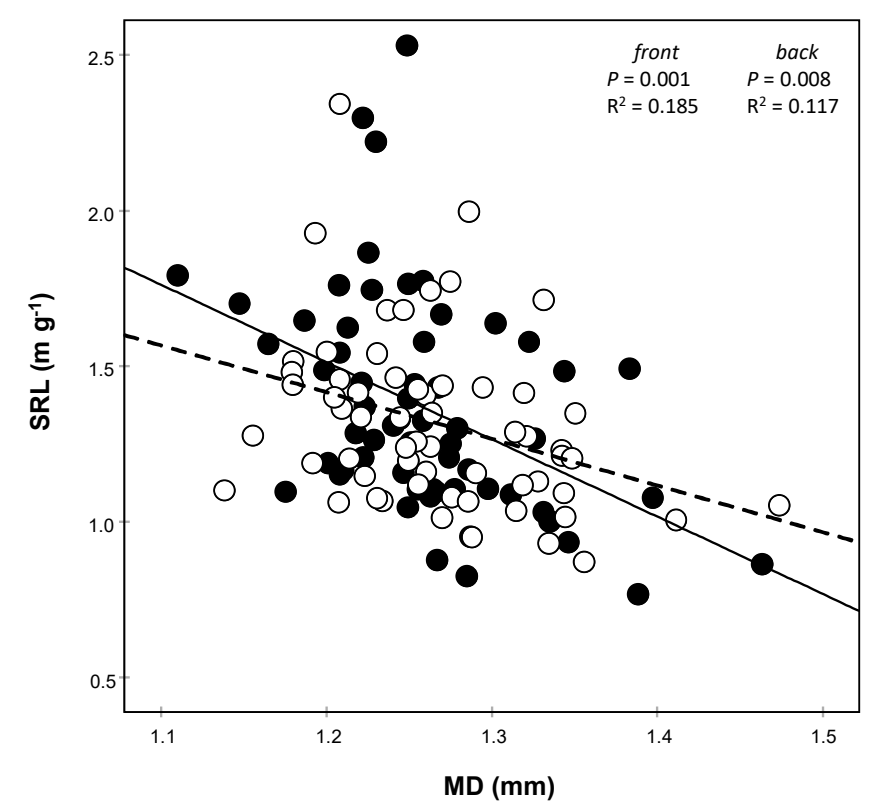

Figure 3. Relationship between specific root length (SRL) and mean diameter (MD) of the 1-2 $\mathrm{mm}$ diameter fine root class according to the front (filled circle) and back (empty circle) core positions. Each point represents the mean of 4 replicates \pm SE. Continuous and dashed lines represent front and back linear interpolations, respectively.

The mean diameter (MD) (Figure 3) rather than the RTD (data not shown) contributed to this slightly higher gap facing, 1-2 mm in diameter SRL, as the relationship was stronger for the gap-facing side. Moreover, the average diameter slightly increased with increasing gap size (Figure S1). Therefore, this result does not support the first hypothesis except for the slightly higher SRL of the larger fine root fraction (1-2 mm).

Unfortunately, no data in the short-term have been collected, making any consideration on fine root dynamics over time merely speculative. Nevertheless, the decrease in fine root biomass following gap openings is supported by other short-term experiments $[8,9]$ ( 6 and 11 months after logging, respectively), which found a consistent decrease at the gap edge, and almost no growth in the center of the gap compared to the adjacent intact forest. Furthermore, regarding the spatial localization of the soil sampling points for edge trees, the adopted distances of 5 and $8 \mathrm{~m}$ from the trunk in the same short-term experiments $[8,9]$ were higher than the $1 \mathrm{~m}$ used in the present work, which fell under the canopy crowns of rather tall trees (on average $31 \mathrm{~m}$ ). In fact, previous findings on the soil characteristics (moisture content, bulk density, total N, P, and soil organic carbon) from the same experimental gaps [45] showed a lack of significant differences between edge and closed canopy trees. These findings also highlighted the low impacts of the adopted management practices on soil characteristics, which did not extend over the medium term [50,51]. This scanty soil alteration might explain the lack of significance of the orientation factor for the edge trees, although a higher soil temperature should be expected for south-faced trees. Therefore, the fine root biomass of edge trees might have been scarcely reduced after gap openings, and the medium-term observation adopted in this work may have been long enough to enable the recovery of fine root biomass to pre-harvest levels, explaining the lack of morphological differences among the gap sizes investigated.

\subsection{Chemical Traits}

Interestingly, $\mathrm{N}$ concentration significantly $(p<0.001)$ increased with increasing size of gaps and significantly $(p<0.001)$ decreased with increasing fine root diameter (Table 2; Figure 4). C concentration did not show any trend in response to the different sizes of the gap, whereas it marginally decreased $(p=0.096)$ with increasing root diameter (Table 2; Figure 4$)$. C:N ratio marginally decreased $(p=0.087)$ with increasing gap size, whereas it 
significantly $(p<0.001)$ increased with increasing fine root diameter (Table 2, Figure 4$)$. It is noteworthy that having pooled the samples did not withhold the clear trend obtained for $\mathrm{N}$ concentration.

Table 2. F and $p$ values of ANCOVA (General Linear Model) for the effects of diameter classes on chemical fine root traits. Gap size was used as a covariate. Interactions were not significant and therefore excluded from the model. Boldface $p$ values are significant at a probability level of $p<0.05$.

\begin{tabular}{ccccc}
\hline Chemical Trait & \multicolumn{2}{c}{ Diam Class $(\mathbf{d f}=\mathbf{2})$} & \multicolumn{2}{c}{ Gap Size $(\mathbf{c})(\mathbf{d f}=\mathbf{1})$} \\
\hline $\mathrm{F}$ & $\boldsymbol{p}$ & $\mathbf{F}$ & $\boldsymbol{p}$ \\
$\mathrm{C}$ & 2.598 & 0.096 & 1.596 & 0.219 \\
$\mathrm{C}: \mathrm{N}$ & 43.73 & $<0.001$ & 25.28 & $<0.001$ \\
Cellulose & 20.89 & $<0.001$ & 3.05 & 0.087 \\
Lignin & 0.374 & 0.692 & 0.024 & 0.879 \\
Cellulose:Lignin & 1.747 & 0.197 & 9.371 & 0.006 \\
Lignin: N & 2.299 & 0.123 & 13.442 & 0.001 \\
\hline
\end{tabular}

(c), covariate.

These findings are in accordance with the literature which reports a strong inverse correlation between $\mathrm{N}$ concentration and root diameter with the highest concentrations in the thinnest root portions $[17,34]$, whereas no consistency emerges on the relationship between $C$ concentration and root diameter [34,52] and references therein. Differently, a lack of consistency persists about the possible $\mathrm{N}$ concentration increase in fine roots in response to gap opening [30], particularly when consequent to artificial gap formation. Most of the studies had focused on alteration on soil processes such as nutrient release during litter decomposition [53,54], microbial activity [45,54], net mineralization and nitrification [55], but few papers concern fine roots $[8,9,11]$. Thinning operations stimulate the $\mathrm{N}$ concentration increase in European beech forests in the Southern Alps, [18], which results in fine roots with a shorter lifespan than those living in the forest left to grow for many years. Findings from the present study suggest a similar response at the fine root level to artificial gap opening derived from single-tree selection practice. Indeed, the lower C:N ratio observed in larger gaps independently of the diameter class highlighted the lower construction costs and, consequently, the more ephemeral nature of these fine roots [34]. Although not differentiated between orientation and core position, these chemical trends would reveal the stimulation of the fine root growth with the increasing size of the gap, with traces still present six years after gap opening.

For cell wall chemical compounds, lignin concentration did not change between diameter classes, but significantly decreased with increasing gap size only for the larger sub-classes, 0.5-1 and 1-2 mm (Table 2, Figure 4). Cellulose also did not differ between the diameter classes and decreased with increasing gap size, but only for the 1-2 mm diameter class. Interestingly, the Cellulose to lignin ratio resulted significantly higher in larger gaps only for the $0.5-1$ and 1-2 mm classes, whereas lignin to $\mathrm{N}$ ratio decreased significantly with increasing gap size for the smaller $<0.5$ and larger 1-2 mm classes, and slightly increased with increasing diameter $(p=0.059)$.

The decrease in the cellulose and lignin in the larger fraction of fine roots with increasing gap size is indicative of roots with thinner secondary walls, and the finding of the slightly higher SRL and lower mean diameter in gap facing 1-2 $\mathrm{mm}$ fine roots (Figure 3) fits to this explanation. Moreover, the increasing trend of the cellulose:lignin ratio with increasing gap size is indicative of a lignin reduction proportionally higher than that of cellulose; the latter, in particular, did not significantly change with the different gap sizes if the last size value was removed from calculation. Xylem percentage area [30] and cellulose:lignin ratio [56-58] increase with the secondary growth and, consequently, increasing diameter. Conversely, RTD decreases with increasing root diameter $[59,60]$ or xylem percentage area [30], although other studies have provided inconsistent results on these relationships [61]. Thus, the slight increase in the average diameter for the 1-2 mm 
class with the increasing size of the gap (Figure S1) marginally correlated with the increasing trend of the cellulose:lignin ratio. Readjustments in crown closure are well known to increase the radial growth in stem and structural roots through the enhancement of photosynthate production $[12,62,63]$, and may have contributed to the moderate $1-2 \mathrm{~mm}$ root class radial growth.

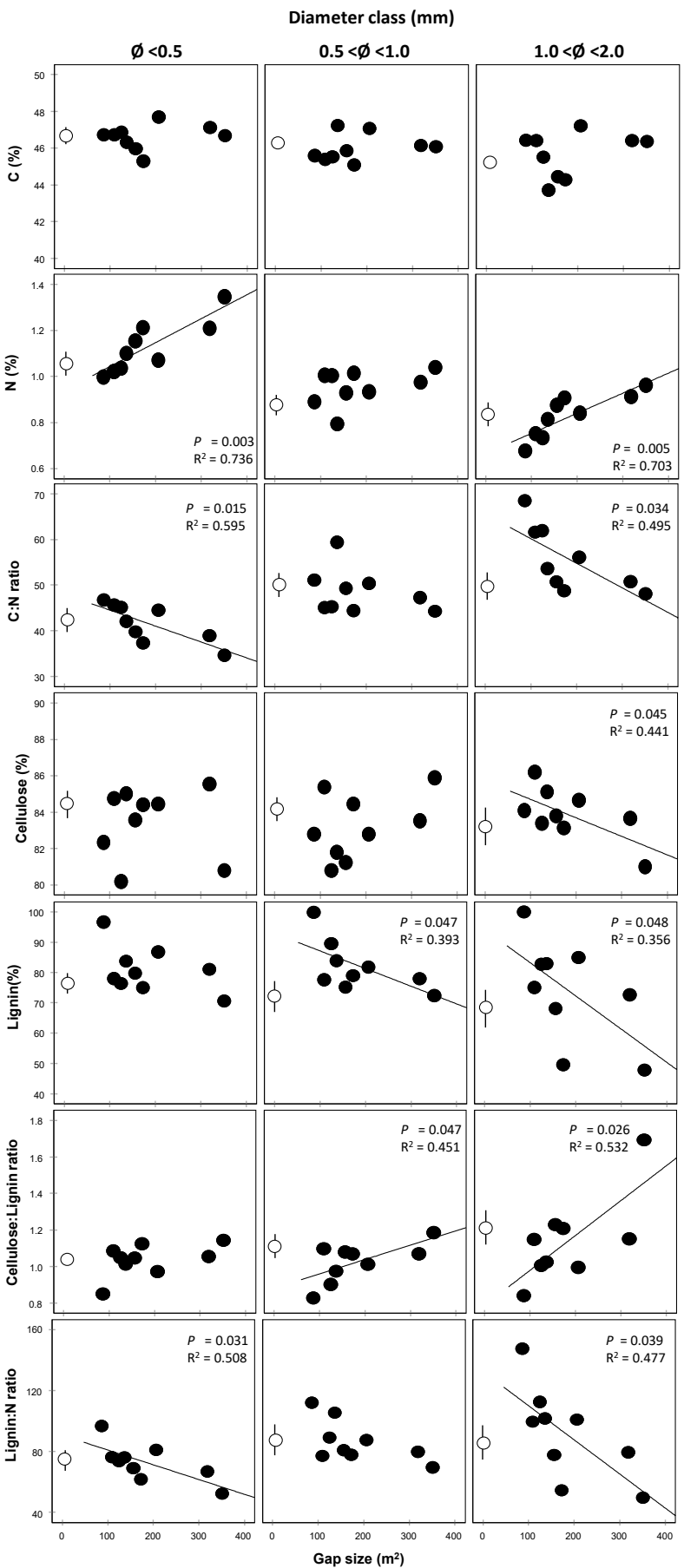

Figure 4. Fine root chemical traits (rows) in relation to gap size, according to three diameter classes $(<0.5,0.5-1$, and 1-2 mm) (columns). Points represent one value per 9 gap sizes only (see Section 2.4); the uncut control, not included in the regression analysis, was conventionally assigned the gap size value of $1 \mathrm{~m}^{2}$ and represents the mean of 9 replicates $\pm \mathrm{SE}$ (see Section 2.5). If significant at $p<0.05$, regression lines and the corresponding $R^{2}$ were shown. 
The cellulose:lignin and Lignin:N ratios, in particular, also belong to those chemical traits of plant litter that have the highest impact on the decomposition rates. The lower Lignin:N ratio with increasing gap size found in the present work could result in higher decomposition rates [64-66]. However, simple extrapolation from the decomposability of root litter to, for example, the long-term carbon sequestration in forest soils is not possible, as additional factors such as the spatial inaccessibility of soil organic matter and organo-mineral interactions cannot be ruled out (e.g., von Lutzow et al. [67]). Thus, differently from the center of gaps, it may be assumed that stimulation of growth near the edge trees was not as remarkable at the morphological level as at it was at the chemical level. This apparent discrepancy between the morphological and chemical traits is explainable in that most of the studies on the effects of gap size on tree fine root dynamics refer to the short-term period, whereas in the present study, the medium term might have veiled the morphological effects not as much as the nitrogen and lignin content in the larger fraction. Morphological and chemical traits are frequently decoupled at the root system level [68]. Indeed, phenotypic plasticity was found to be limited across soil conditions and growing seasons for several temperate species $[16,69,70]$. Similarly, a correlation between morphological traits such as SRL and $\mathrm{N}$ concentration was lacking for fine roots of many softwood and hardwood North American species [68,71].

\section{Conclusions}

This work highlights that, in the medium term and within the adopted size range, artificial gap opening derived from single-tree selection practice affected the chemistry rather than the biomass and morphology of gap-facing fine roots in oriental beech edge trees. These outcomes suggest that the below-ground carbon stock is not influenced in the medium term by the forest gap openness following single-tree selection practice, but readjustments in the crown closure of edge trees may contribute to a moderate radial growth in the larger and woodier fine root fraction. Consequently, the derived increase in $\mathrm{C}: \mathrm{N}$ and decrease in Lignin: $\mathrm{N}$ ratios with increasing gap size may increase the fine root decomposition, and subsequently the carbon input into the soil as medium-long-term implication. A clear size threshold did not come out since the trends with increasing gap size were either absent for the morphological or continuous for the chemical traits. Nevertheless, for this latter, $300 \mathrm{~m}^{2}$ may be considered a possible cut-off determining a marked change in the responses of fine roots.

Supplementary Materials: The following are available online at https:/ / www.mdpi.com/1999-490 7/12/2/137/s1, Figure S1: Specific root length (SRL) and mean diameter (rows) in relation to gap size of the 1-2 mm diameter fine root class, Table S1: Size of the 15 studied gaps and the related tree-edge characteristics.

Author Contributions: Conceptualization, K.A.V., A.A.K., M.F., and A.D.I.; methodology, K.A.V., A.A.K., M.F., A.M., A.D.I.; investigation, A.A.K., M.F., K.A.V.; software, A.D.I., A.A.K. and A.M.; formal analysis, A.D.I., A.A.K. and A.M.; data curation, A.D.I., A.A.K.; writing-original draft preparation, A.A.K., K.A.V.; writing—review and editing, A.D.I., A.M.; visualization, A.D.I.; supervision, K.A.V., A.D.I.; funding acquisition, K.A.V., A.D.I. All authors have read and agreed to the published version of the manuscript.

Funding: This study was supported by Lorestan University, Lorestan, Iran and the University of Insubria (FAR no. 2019).

Data Availability Statement: The datasets generated during the current study are available from the corresponding author on reasonable request.

Acknowledgments: The authors are grateful to Lorestan University, Lorestan, Iran, and the University of Insubria (University Research Funding-project FAR) to provide us with financial supports. Special thanks to Enrico Caruso for his technical support with the Soxhlet system for cellulose quantification, Delle Fratte Michele for assistance with the CHN analysis. The authors gratefully acknowledge the two anonymous reviewers for their valuable comments. 
Conflicts of Interest: The authors declare no conflict of interest.

\section{References}

1. Wang, C.; Brunner, I.; Zong, S.; Li, M.-H. The Dynamics of Living and Dead Fine Roots of Forest Biomes Across the Northern Hemisphere. Forests 2019, 10, 953. [CrossRef]

2. Finér, L.; Ohashi, M.; Noguchi, K.; Hirano, Y. Fine root production and turnover in forest ecosystems in relation to stand and environmental characteristics. For. Ecol. Manag. 2011, 262, 2008-2023. [CrossRef]

3. Železnik, P.; Vilhar, U.; Starr, M.; De Groot, M.; Kraigher, H. Fine root dynamics in Slovenian beech forests in relation to soil temperature and water availability. Trees 2016, 30, 375-384. [CrossRef]

4. Finér, L.; Ohashi, M.; Noguchi, K.; Hirano, Y. Factors causing variation in fine root biomass in forest ecosystems. For. Ecol. Manag. 2011, 261, 265-277. [CrossRef]

5. Yuan, Z.; Chen, H.Y. Fine root biomass, production, turnover rates, and nutrient contents in boreal forest ecosystems in relation to species, climate, fertility, and stand age: Literature review and meta-analyses. Crit. Rev. Plant. Sci. 2010, 29, 204-221. [CrossRef]

6. Jackson, R.B.; Mooney, H.A.; Schulze, E.D. A global budget for fine root biomass, surface area, and nutrient contents. Proc. Natl. Acad. Sci. USA 1997, 94, 7362-7366. [CrossRef]

7. Vogt, K.A.; Vogt, D.J.; Bloomfield, J. Analysis of some direct and indirect methods for estimating root biomass and production of forests at an ecosystem level. Plant Soil 1998, 200, 71-89. [CrossRef]

8. Bauhus, J.; Bartsch, N. Fine-root growth in beech (Fagus sylvatica) forest gaps. Can. J. For. Res. 1996, 26, 2153-2159. [CrossRef]

9. Brockway, D.G.; Outcalt, K.W. Gap-phase regeneration in longleaf pine wiregrass ecosystems. For. Ecol. Manag. 1998, 106, 125-139. [CrossRef]

10. Montagnoli, A.; Terzaghi, M.; Di Iorio, A.; Scippa, G.S.; Chiatante, D. Fine-root seasonal pattern, production and turnover rate of European beech (Fagus sylvatica L.) stands in Italy Prealps: Possible implications of coppice conversion to high forest. Plant Biosyst. 2012, 146, 1012-1022. [CrossRef]

11. Jones, R.H.; Mitchell, R.J.; Stevens, G.N.; Pecot, S.D. Controls of fine root dynamics across a gradient of gap sizes in a pine woodland. Oecologia 2003, 134, 132-143. [CrossRef] [PubMed]

12. Di Iorio, A.; Montagnoli, A.; Terzaghi, M.; Scippa, G.S.; Chiatante, D. Effect of tree density on root distribution in Fagus sylvatica stands: A semi-automatic digitising device approach to trench wall method. Trees Struct. Funct. 2013, 27, 1503-1513. [CrossRef]

13. Ostonen, I.; Püttsepp, Ü.; Biel, C.; Alberton, O.; Bakker, M.R.; Lõhmus, K.; Majdi, H.; Metcalfe, D.; Olsthoorn, A.F.M.; Pronk, A.; et al. Specific root length as an indicator of environmental change. Plant Biosyst. 2007, 141, 426-442. [CrossRef]

14. Amendola, C.; Montagnoli, A.; Terzaghi, M.; Trupiano, D.; Oliva, F.; Baronti, S.; Miglietta, F.; Chiatante, D.; Scippa, G.S. Short-term effects of biochar on grapevine fine root dynamics and arbuscular mycorrhizae production. Agric. Ecosyst. Environ. 2017, 239, 236-245. [CrossRef]

15. Withington, J.M.; Reich, P.B.; Oleksyn, J.; Eissenstat, D.M. Comparisons of structure and life span in roots and leaves among temperate trees. Ecol. Monogr. 2006, 76, 381-397. [CrossRef]

16. Zadworny, M.; McCormack, M.L.; Rawlik, K.; Jagodziński, A.M. Seasonal variation in chemistry, but not morphology, in roots of Quercus robur growing in different soil types. Tree Physiol. 2015, 35, 644-652. [CrossRef]

17. Li, A.; Guo, D.; Wang, Z.; Liu, H. Nitrogen and phosphorus allocation in leaves, twigs, and fine roots across 49 temperate, subtropical and tropical tree species: A hierarchical pattern. Funct. Ecol. 2010, 24, 224-232. [CrossRef]

18. Terzaghi, M.; Montagnoli, A.; Di Iorio, A.; Scippa, G.S.; Chiatante, D. Fine-root carbon and nitrogen concentration of European beech (Fagus sylvatica L.) in Italy Prealps: Possible implications of coppice conversion to high forest. Front. Plant Sci. $2013,4,192$. [CrossRef]

19. Vajari, K.A.; Jalilvand, H.; Pourmajidian, M.R.; Espahbodi, K.; Moshki, A. The effect of single-tree selection system on soil properties in an oriental beech stand of Hyrcanian forest, north of Iran. J. For. Res. 2011, 22, 591-596. [CrossRef]

20. Sommerfeld, R.; Lundquist, J.; Smith, J. Characterizing the canopy gap structure of a disturbed forest using the Fourier transform. For. Ecol. Manag. 2000, 128, 101-108. [CrossRef]

21. Miller, S.D.; Goulden, M.L.; da Rocha, H.R. The effect of canopy gaps on subcanopy ventilation and scalar fluxes in a tropical forest. Agric. For. Meteorol. 2007, 142, 25-34. [CrossRef]

22. Vepakomma, U.; St-Onge, B.; Kneeshaw, D. Spatially explicit characterization of boreal forest gap dynamics using multi-temporal lidar data. Remote Sens. Environ. 2008, 112, 2326-2340. [CrossRef]

23. Kukkonen, M.; Rita, H.; Hohnwald, S.; Nygren, A. Treefall gaps of certified, conventionally managed and natural forests as regeneration sites for Neotropical timber trees in northern Honduras. For. Ecol. Manag. 2008, 255, 2163-2176. [CrossRef]

24. Cannon, J.B.; Brewer, J.S. Effects of Tornado Damage, Prescribed Fire, and Salvage Logging on Natural Oak (Quercus spp.) Regeneration in a Xeric Southern USA Coastal Plain Oak and Pine Forest. Nat. Areas J. 2013, 33, 39-49. [CrossRef]

25. Izbicki, B.J.; Alexander, H.D.; Paulson, A.K.; Frey, B.R.; McEwan, R.W.; Berry, A.I. Prescribed fire and natural canopy gap disturbances: Impacts on upland oak regeneration. For. Ecol. Manag. 2020, 465, 118107. [CrossRef]

26. Gagnon, J.L.; Jokela, E.J.; Moser, W.; Huber, D.A. Characteristics of gaps and natural regeneration in mature longleaf pine flatwoods ecosystems. For. Ecol. Manag. 2004, 187, 373-380. [CrossRef]

27. Yamamoto, S.-I. Forest Gap Dynamics and Tree Regeneration. J. For. Res. 2000, 5, 223-229. [CrossRef] 
28. Schnabel, F.; Donoso, P.J.; Winter, C. Short-term effects of single-tree selection cutting on stand structure and tree species composition in Valdivian rainforests of Chile. New Zeal. J. For. Sci. 2017, 47, 21. [CrossRef]

29. Muscolo, A.; Bagnato, S.; Sidari, M.; Mercurio, R. A review of the roles of forest canopy gaps. J. For. Res. 2014, 25, 725-736. [CrossRef]

30. Zhu, J.J.; Tan, H.; Li, F.Q.; Chen, M.; Zhang, J.X. Microclimate regimes following gap formation in a montane secondary forest of eastern Liaoning Province, China. J. For. Res. 2007, 18, 167-173. [CrossRef]

31. Kooch, Y.; Bayranvand, M. Composition of tree species can mediate spatial variability of C and $\mathrm{N}$ cycles in mixed beech forests. For. Ecol. Manag. 2017, 401, 55-64. [CrossRef]

32. Guner, S.; Yagci, V.; Tilki, F.; Celik, N. The effects of initial planting density on above-and below-ground biomass in a 25-year-old Fagus orientalis Lipsky plantation in Hopa, Turkey. Sci. Res. Essays 2010, 5, 1856-1860.

33. Brassard, B.W.; Chen, H.Y.H.; Bergeron, Y. Influence of environmental variability on root dynamics in northern forests. CRC Crit. Rev. Plant Sci. 2009, 28, 179-197. [CrossRef]

34. Pregitzer, K.S.; DeForest, J.L.; Burton, A.J.; Allen, M.F.; Ruess, R.W.; Hendrick, R.L. Fine root architecture of nine North American trees. Ecol. Monogr. 2002, 72, 293-309. [CrossRef]

35. Guo, D.; Xia, M.; Wei, X.; Chang, W.; Liu, Y.; Wang, Z. Anatomical traits associated with absorption and mycorrhizal colonization are linked to root branch order in twenty-three Chinese temperate tree species. New Phytol. 2008, 180, 673-683. [CrossRef]

36. Pregitzer, K.S.; Zak, D.R.; Loya, W.M.; Karberg, N.J.; King, J.S.; Burton, A.J. The Contribution of Root-Rhizosphere Interactions to Biogeochemical Cycles in a Changing World. In The Rhizosphere: An Ecological Perspective; Cardon, Z.G., Whitbeck, J.L., Eds.; Elsevier Academic Press: Burlington, MA, USA, 2007; pp. 155-178. ISBN 9780120887750.

37. Withington, J.M.; Elkin, A.D.; Bułaj, B.; Olesiński, J.; Tracy, K.N.; Bouma, T.J.; Oleksyn, J.; Anderson, L.J.; Modrzyński, J.; Reich, P.B.; et al. The impact of material used for minirhizotron tubes for root research. New Phytol. 2003, 160, 533-544. [CrossRef]

38. Long, Y.; Kong, D.; Chen, Z.; Zeng, H. Variation of the linkage of root function with root branch order. PLoS ONE 2013, 8, e57153. [CrossRef]

39. Iversen, C.M. Using root form to improve our understanding of root function. New Phytol. 2014, 203, 707-709. [CrossRef]

40. Montagnoli, A.; Terzaghi, M.; Giussani, B.; Scippa, G.S.; Chiatante, D. An integrated method for high-resolution definition of new diameter-based fine root sub-classes of Fagus sylvatica L. Ann. For. Sci. 2018, 75, 76. [CrossRef]

41. Montagnoli, A.; Terzaghi, M.; Di Iorio, A.; Scippa, G.S.; Chiatante, D. Fine-root morphological and growth traits in a Turkey-oak stand in relation to seasonal changes in soil moisture in the Southern Apennines, Italy. Ecol. Res. 2012, 27, 1015-1025. [CrossRef]

42. Montagnoli, A.; Di Iorio, A.; Terzaghi, M.; Trupiano, D.; Scippa, G.S.; Chiatante, D. Influence of soil temperature and water content on fine-root seasonal growth of European beech natural forest in Southern Alps, Italy. Eur. J. For. Res. 2014, 133, 957-968. [CrossRef]

43. Montagnoli, A.; Dumroese, R.K.; Terzaghi, M.; Onelli, E.; Scippa, G.S.; Chiatante, D. Seasonality of fine root dynamics and activity of root and shoot vascular cambium in a Quercus ilex L. forest (Italy). For. Ecol. Manag. 2019, 431, 26-34. [CrossRef]

44. Yoshida, T.; Naito, S.; Nagumo, M.; Hyodo, N.; Inoue, T.; Umegane, H.; Yamazaki, H.; Miya, H.; Nakamura, F. Structural Complexity and Ecosystem Functions in a Natural Mixed Forest under a Single-Tree Selection Silviculture. Sustainability 2017, 9 , 2093. [CrossRef]

45. Alireza, A.; Abrari, V.K.; Mohammad, F.; Antonino, D.I. Influences of forest gaps on soil physico-chemical and biological properties in an oriental beech (Fagus orientalis L.) stand of Hyrcanian forest, north of Iran. iForest 2020, 13, 124-129.

46. Leavitt, S.W.; Danzer, S.R. Method for Batch Processing Small Wood Samples to Holocellulose for Stable-Carbon Isotope Analysis. Anal. Chem. 1993, 65, 87-89. [CrossRef]

47. Genet, M.; Stokes, A.; Salin, F.; Mickovski, S.B.; Fourcaud, T.; Dumail, J.F.; Van Beek, R. The influence of cellulose content on tensile strength in tree roots. Plant Soil 2005, 278, 1-9. [CrossRef]

48. Doster, M.A.; Bostock, R.M. Quantification of Lignin Formation in Almond Bark in Response to Wounding and Infection by Phytophthora Species. Phytopathology 1988, 78, 473. [CrossRef]

49. Trupiano, D.; Di Iorio, A.; Montagnoli, A.; Lasserre, B.; Rocco, M.; Grosso, A.; Scaloni, A.; Marra, M.; Chiatante, D.; Scippa, G.S. Involvement of lignin and hormones in the response of woody poplar taproots to mechanical stress. Physiol. Plant. 2012, 146, 39-52. [CrossRef]

50. Cambi, M.; Certini, G.; Neri, F.; Marchi, E. The impact of heavy traffic on forest soils: A review. For. Ecol. Manag. 2015, 338, 124-138. [CrossRef]

51. Gray, A.N.; Spies, T.A.; Easter, M.J. Microclimatic and soil moisture responses to gap formation in coastal Douglas-fir forests. Can. J. For. Res. 2002, 32, 332-343. [CrossRef]

52. Terzaghi, M.; Di Iorio, A.; Montagnoli, A.; Baesso, B.; Scippa, G.S.; Chiatante, D. Forest canopy reduction stimulates xylem production and lowers carbon concentration in fine roots of European beech. For. Ecol. Manag. 2016, 379, 81-90. [CrossRef]

53. Ni, X.; Berg, B.; Yang, W.; Li, H.; Liao, S.; Tan, B.; Yue, K.; Xu, Z.; Zhang, L.; Wu, F. Formation of forest gaps accelerates C, N and P release from foliar litter during 4 years of decomposition in an alpine forest. Biogeochemistry 2018, 139, 321-335. [CrossRef]

54. Scharenbroch, B.C.; Bockheim, J.G. Impacts of forest gaps on soil properties and processes in old growth northern hardwoodhemlock forests. Plant Soil 2007, 294, 219-233. [CrossRef]

55. Parsons, W.F.J.; Knight, D.H.; Miller, S.L. Root Gap Dynamics in Lodgepole Pine Forest: Nitrogen Transformations in Gaps of Different Size. Ecol. Appl. 1994, 4, 354-362. [CrossRef] 
56. Thomas, F.M.; Molitor, F.; Werner, W. Lignin and cellulose concentrations in roots of Douglas fir and European beech of different diameter classes and soil depths. Trees-Struct. Funct. 2014, 28, 309-315. [CrossRef]

57. Zhang, C.B.; Chen, L.H.; Jiang, J. Why fine tree roots are stronger than thicker roots: The role of cellulose and lignin in relation to slope stability. Geomorphology 2014, 206, 196-202. [CrossRef]

58. Zhu, J.; Wang, Y.; Wang, Y.; Mao, Z.; Langendoen, E.J. How does root biodegradation after plant felling change root reinforcement to soil? Plant Soil 2020, 446, 211-227. [CrossRef]

59. McCormack, M.L.; Iversen, C.M. Physical and Functional Constraints on Viable Belowground Acquisition Strategies. Front. Plant Sci. 2019, 10, 1-12. [CrossRef]

60. Kong, D.; Wang, J.; Wu, H.; Valverde-Barrantes, O.J.; Wang, R.; Zeng, H.; Kardol, P.; Zhang, H.; Feng, Y. Nonlinearity of root trait relationships and the root economics spectrum. Nat. Commun. 2019, 10, 1-9. [CrossRef]

61. Kramer-Walter, K.R.; Bellingham, P.J.; Millar, T.R.; Smissen, R.D.; Richardson, S.J.; Laughlin, D.C. Root traits are multidimensional: Specific root length is independent from root tissue density and the plant economic spectrum. J. Ecol. 2016, 104, 1299-1310. [CrossRef]

62. Fayle, D.C.F. Distribution of radial growth during the development of red pine root systems. Can. J. For. Res. 1975, 5, 608-625. [CrossRef]

63. Vincent, M.; Krause, C.; Zhang, S.Y. Radial growth response of black spruce roots and stems to commercial thinning in the boreal forest. Forestry 2009, 82, 557-571. [CrossRef]

64. Talbot, J.M.; Treseder, K.K. Interactions among lignin, cellulose, and nitrogen drive litter chemistry-decay relationships. Ecology 2012, 93, 345-354. [CrossRef] [PubMed]

65. Walela, C.; Daniel, H.; Wilson, B.; Lockwood, P.; Cowie, A.; Harden, S. The initial lignin: Nitrogen ratio of litter from above and below ground sources strongly and negatively influenced decay rates of slowly decomposing litter carbon pools. Soil Biol. Biochem. 2014, 77, 268-275. [CrossRef]

66. Zhang, X.; Wang, W. The decomposition of fine and coarse roots: Their global patterns and controlling factors. Sci. Rep. 2015, 5, 1-10. [CrossRef]

67. Lützow, M.V.; Kögel-Knabner, I.; Ekschmitt, K.; Matzner, E.; Guggenberger, G.; Marschner, B.; Flessa, H. Stabilization of organic matter in temperate soils: Mechanisms and their relevance under different soil conditions-A review. Eur. J. Soil Sci. 2006, 57, 426-445. [CrossRef]

68. Valverde-Barrantes, O.J.; Smemo, K.A.; Blackwood, C.B. Fine root morphology is phylogenetically structured, but nitrogen is related to the plant economics spectrum in temperate trees. Funct. Ecol. 2015, 29, 796-807. [CrossRef]

69. Comas, L.H.; Eissenstat, D.M.; Lakso, A.N. Assessing root death and root system dynamics in a study of grape canopy pruning. New Phytol. 2000, 147, 171-178. [CrossRef]

70. Lee, M.H.; Comas, L.H.; Callahan, H.S. Experimentally reduced root-microbe interactions reveal limited plasticity in functional root traits in Acer and Quercus. Ann. Bot. 2014, 113, 513-521. [CrossRef]

71. Comas, L.H.; Eissenstat, D.M. Patterns in root trait variation among 25 co-existing North American forest species. New Phytol. 2009, 182, 919-928. [CrossRef] 